\title{
SUSTAINABLE LOCAL DEVELOPMENT THROUGH THE SEARCH FOR AND IMPLEMENTATION OF GOOD PRACTICES IN WASTE MANAGEMENT
}

\author{
Mariusz Dacko ${ }^{1}$, Phd Eng.; Aleksandra Plonka², Phd Eng. \\ 1,2 University of Agriculture in Krakow
}

\begin{abstract}
Waste management is a vital issue, both in terms of the environmental protection and due to socioeconomic considerations. It has attracted the interest of modern economics, as evidenced by the extensive literature addressing the issue of production and waste management from the perspective of sustainable development. Solutions in the area of waste collection and separation, minimisation of waste quantity and search for new applications for waste are plentiful. They are a determinant of social responsibility for the present and future generations, thus becoming one of the key aspects of sustainable development. The paper reviewed such solutions. The aim of the study was to indicate actions that can be taken to improve local systems of waste management. One of the most interesting was the Japanese waste collection system that enforces the reliability of segregation and bottom-up social waste minimization movements.
\end{abstract}

Key words: waste, sustainable development, local community, good practices JEL code: Q56.

\section{Introduction}

The commitment to minimising the quantity of waste and achieving a high level of its separation and recovery is currently a challenge to every commune that takes seriously the postulate of intergenerational justice, which is a key element of the definition of sustainable development. This commitment can be delivered more effectively by searching for and implementing tried and tested good practice. Waste management can also be improved by an appropriate selection of organisational and economic instruments and using them to shape social attitudes consistent with the idea of sustainable development.

The paper presented examples of interesting solutions in municipal waste management that have been implemented in practice. The main aim of the study was to indicate specific actions that can be taken to improve waste management systems. Attention was focused, among other things, on waste collection and search for the ways to reduce its quantity. The paper addressed the issue of motivating inhabitants to separate waste and that of controlling and correcting the process of waste disposal. It presented selected solutions employed by local authorities as well as bottom-up social initiatives facilitating sustainable development.

\section{Sustainable development and waste management}

Sustainable development is at the heart of the European Union's policy. It is manifested in numerous sources of universal law within the Community, i.e. in EU regulations applicable to all the member states and directives that have to be implemented into the national law. For many years, it has also been underlying EU strategies and programmes of actions to promote the protection of the environment. At the level of EU member states, the obligation to follow the principles of sustainable development was introduced into the laws concerning the protection and management of environmental resources and into the local law (Dacko M., Dacko A., 2018). Thus, by extension, the principles of sustainable development must govern waste management. However, the

\footnotetext{
1 Mariusz Dacko PhD Eng.; The University of Agriculture in Krakow, Poland

The Faculty of Agriculture and Economics, the Institute of Economic and Social Sciences, the Department of Economics and Organization of Agriculture,

e-mail: m.dacko@ur.krakow.pl

2 Aleksandra Plonka PhD Eng.; The University of Agriculture in Krakow, Poland

The Faculty of Agriculture and Economics, the Institute of Economic and Social Sciences, the Department of Economics and Organization of Agriculture,

e-mail: a.plonka@ur.krakow.pl (corresponding author)
} 
implementation of the idea of sustainable development into the life of local communities encounters problems, as was critically assessed, among others, by W. Sztumski (2006). The author expresses a pessimistic view that sustainable development is based more on wishful than practical thinking. According to T. Zylicz (2010), the declarative and normative character of the postulates of sustainable development may result in disappointment - people do not act as their best interest require them to act. Similar issues were also emphasised by G. Hardin (1968), who noted that carefree waste management is a typical example of the tragedy of the commons, i.e. the mechanism under which maximisation of individual gains leads to problems that cannot be solved individually. Controversies around sustainable development in terms of terminology and implementation are plentiful (Dacko M., 2011a). Nevertheless, sustainable development is regarded in social sciences as best practice in modern civilisation (Poskrobko B., 2013; Kuder D., 2014; Matysiak A., StruS M., 2015; Zadroga A., 2016). It involves searching for and implementing such solutions that will allow the current needs of a society to be met without preventing the satisfaction of the needs of future generations. This idea is considered in modern economics in terms of a paradigm, which is supposed to replace the obsolete primacy of economic growth. For waste management, it means seeking such solutions that will ensure constructiveness of the economy-environment relationship, thus allowing these systems not to be mutually exclusive. It requires frugal and effective use of resources and the ability to put limits on one's own needs, while striving to find uses for the waste that could not have been avoided (Dacko M., 2011a; Dacko M., 2011b).

\section{Good practice and solutions in the area of waste management}

When reviewing interesting solutions in the area of waste management, it is worth starting with an example that should serve as a warning. It shows how serious the problems of unordered waste management and carefree waste storage can be. In the Italian region of Campania, which was affected by a waste crisis, corruption and mafia interests led to a situation where for many years waste business involved seeking cheap and convenient solutions. Mixed waste was stored on increasingly overfull landfill sites, and as they were closed, Naples experienced states of waste emergency (in 2001, 2003 and 2007, among other things) "sinking" in waste that it was unable to dispose of. The mixed waste generated odour, which lingered in streets and at illegal landfill sites. It was accompanied by an unprecedented invasion of insects and rodents. In many places in the city, piles of waste stored on streets blocked the traffic. Alarms were raised about a huge risk of infectious diseases: hepatitis, cholera, typhoid, salmonella and leptospirosis. The effects of such waste management were disastrous, not only for the natural environment, but also for the society. During a period of 20 years, Naples recorded a $40 \%$ increase in the number of cases of cancer among females and a $47 \%$ increase among males (Wielki..., 2013). However nothing was done to overcome the powerlessness in the face of the needs for radical systemic changes. When it turned out that the neighbouring regions did not want to accept Naples's mixed waste, it was transported to Germany, Poland, Romania and other countries (Zobaczyc..., 2007).

The waste crisis in Campania did not happen of itself or accidentally. It was a result of a moral crisis among the region's inhabitants and their elites. Italian economist Paolo Leon put it bluntly: "The man of the South directs all his intellectual work at cheating the state and taking some money for himself" (Zobaczyc..., 2010). Naples became a special case of a region whose huge tourist potential was undermined by a disastrous sanitary and epidemiological situation: the effect of persistently sticking to an outdated model of waste management. 
It is crucial to seek good practice in waste management not only at the level of general solutions applied in the different countries and their regions. Reliable solutions can and should be implemented by communes as key players in the local processes of waste management. However, it should be added at this point that at the local level the issue of waste is not only determined by the decisions of local authorities which the community has to respect. In the area of waste, we are increasingly seeing various interesting forms of social self-organisation. Both households and enterprises are actively engaged in it.

Jan Tinbergen - economist and Nobel Prize winner, expressed a view worth citing here after Schultink G. (2007): two things are unlimited - the number of generations we should feel responsible for and our ingenuity. The first represents a challenge to us. The second - our ingenuity - can generate ideas that will contribute to meeting this challenge. The present-day world provides a lot of examples confirming that human ingenuity is limitless, also with respect to the ways of waste management. In the era of the paradigm of sustainable development, local authorities should not only keep a close eye on such initiatives, but also support them (e.g. through a tax policy, publicprivate partnership, or the idea of green public procurement).

P. Hawken (1996) presents an example of a US carpet manufacturer who substituted the sale of goods with the sale of services. As a result, a worn-out or unnecessary carpet is returned to its manufacturer who is responsible for handling it as waste. One of the world's largest IT enterprises US Hewlett-Packard - has for a dozen or so years been recovering plastic from ink cartridges reusing it in the processes of manufacturing new printers (Co mozna..., 2010). Recovery and reuse of raw materials are becoming the standard in modern economy. In Holland, freon is pumped out of old fridges in the first place. Then, on a special production line, fridges are disintegrated, and metal is separated from plastic using magnet. It is processed into a fine granulated product, and then used as material for 3D printers in the production of artificial limbs for humans. The company Timberland hires citizens of Honduras and Haiti to collect plastic bottles, which it then uses to prepare material from which it makes shoes (Ekonomia..., 2017). In Denmark, beer bottles are used even 40 times thanks to the implementation of an automatic washing, condition control (crack and scratch assessment) and relabelling technology. But the company Carlsberg has gone even further - in the near future, it intends to introduce a biodegradable bottle made of plant fibre (Carlsberg..., 2018). The philosophy "product without packaging" is also implemented in Poland. Its example is milk dispensers, which allow raw, unprocessed milk to be bought. When using a milk dispenser, one should bring own vessel or buy a bottle in the machine.

Analysis of waste treatment solutions adopted by local authorities shows that where such solutions are complicated waste disposal can become a serious task. In Japan, individual prefectures' instructions concerning preparing waste for collection, as developed for the inhabitants, may even number a few dozen pages (Smieci..., 2013). They usually distinguish a large number of waste categories and specify detailed principles of handling them. For instance, paper has to be tied with string, plastic bottles have to be crushed, and when toys (which usually contain electronics) are thrown away, they have to be taken pieces so as to separate plastic from metal. With so many detailed principles to follow, separation takes a lot of time, requires exceptional discipline and makes this sphere one of more serious issues in the day-to-day life of the Japanese. This provokes a reflection that solutions that require so much discipline would hardly meet with social acceptance in the Western Civilisation. However, in Japan the mechanism of waste collection also includes other interesting solutions that enforce scrupulous separation. An example is the principle that waste is 
collected only if it is placed in front of the door on certain dates, in transparent bags and labelled with the owner's full name and address. Thus, the inhabitants dispose of waste in a non-anonymous way and in case of any doubts about whether the waste was prepared scrupulously enough, the services leave the bags uncollected and their owners have to prepare them better for the next collection.

Similar solutions are used in Poland. In one commune, holders of waste dispose of it by sticking labels with a bar code on the bags (Gospodarka..., 2018). Each bar code is assigned to a specific property address. If a bag lacks a label, it is impossible to scan a bare code, and the waste producer cannot be identified. The bag with waste will not be collected. Each such case is photographed and described, and then sent to the Commune Office in the form of documentary evidence (System..., 2018). Many other local authorities in Poland go in a similar direction. Other solutions include marking waste bags with an individual number assigned by the commune to every household. An interesting initiative was planned to be implemented in one of Polish cities. A special application for mobile phones would enable people to report a neighbour who failed to separate their waste to the authorities (Sprawdza..., 2015). Modern technologies open up completely new possibilities in detection of waste disposal violations. For instance, there are already drones that can successfully indicate houses where waste is incinerated (Dron..., 2019).

However, in the sphere of waste, the problem is not only the lack of environmental education among inhabitants, but also gaps in communes' waste management systems, which prevent successful elimination of illegal practices. In one of Polish cities, an interesting attempt was made to solve the problem of illegal practices by making it easier for inhabitants to dispose of their problematic waste. A system of waste management was implemented that was based on dividing waste into dry and wet groups, with one of the most important element of the system being the socalled "junk room." This is a place where all hazardous and problematic waste is collected free of charge from inhabitants without any quantitative limits. In addition, efforts were taken to reduce the quantity of bulky waste by organising the so-called "corner of used things." This is where inhabitants can leave the furniture they No longer need at home, chairs, tables, toys, ceramic articles and glassware as well as household appliances and home electronics. The objects must be still in working condition and undamaged. When there is a "buyer" for any of the objects, he/she takes it for free, filling out a document of gratuitous purchase. What does not find a buyer during a period of 3 months is transferred to a waste zone (Kacik..., 2016).

Independently of local authorities' efforts in the area of waste, people are able to organise themselves in a quite interesting way. A family in California has been living for several years following the zero waste principle. Four people generate one jar of rubbish in a year thanks to almost complete elimination of waste from their life (Zero waste, 2019). The system involves avoiding everything that is disposable - it is based on second-hand goods, borrowing and sharing, own production and repairs, and preferring high quality and durable things. Since the family was described in the New York Times, zero waste has gained in popularity, and the initiator of this movement was approached by companies and institutions (including IKEA and General Electrics) that entered into cooperation with her. In Berlin and Cape Town, first wasteless shops have even been opened (Swiat..., 2018). Bea Johnson the author of the idea of zero waste - successfully tries to inspire local communities during her lectures. In Europe, the zero waste movement has found a fertile soil. Also in Poland, the first Zero Waste Poland group emerged (Zero waste, 2019). 
An equally noteworthy initiative fitting into the bottom-up social movement of waste minimisation is the so-called repair cafés, which were started by Martine Postma in 2009 in Amsterdam. The idea behind this initiative is that a group of specialist service technicians from various fields get together for a coffee and cake and repair free of charge things that would have become waste. This is also an occasion to make new friends, people get to know each other, have discussions and share their experiences. In Poland, the first repair café meeting took place in 2018 in Warsaw and received very positive opinions (Pierwsza..., 2018).

A similar initiative is sewing cafés. People meet, have a coffee and learn how to sew. Also in this case, it is about relationships and a nice atmosphere. In the cafés, you can buy sewing accessories, equipment and materials. There are thematic courses and trainings organised for those interested. Such facilities operate in at least several large Polish cities. The effect is similar as in the case of repair cafés. Old things are given a new life, and by altering and mending them less waste is produced.

An interesting example of bottom-up initiatives was recorded in one of Polish communes, where a patrol and prevention unit called EKO-PATROL is operating. It is run by the voluntary fire department's youth team. Its members take actions if environmental misconduct on the part of residents is found (e.g. they prevent the littering of public spaces, control illegal landfill sites, prevent fire risks caused by the burning of grass). Any irregularities identified by EKO-PATROL are reported to relevant services so that appropriate intervention can be undertaken.

When it comes to waste minimisation, the Internet provides huge possibilities. One such example is a very popular website in Poland, OLX.pl, where local announcements can be posted free of charge. It is unique compared to Allegro or Ebay, as it has such categories as "I'll give away for free" and "I'll exchange." Thanks to these two categories, before an unneeded thing becomes waste, it can find a new owner without any additional costs involved. The Internet has also become the "engine" of a very interesting Polish start-up, i.e. a trading platform designed to help to sell food with the useby date coming soon and thereby to reduce the waste of food.

In order to reduce waste in Western Europe, for many years there has been a custom of putting unnecessary things outside, and in some countries (e.g. Belgium) fairs are even organised in housing estates. The residents open their garages and put outside things they want to get rid of. People get together, chat, negotiate prices, and things that are not needed in one household (clothes, shoes, furniture, electronics, household appliances) find a use in the neighbourhood. Not only they do not have to be thrown away, but also, thanks to such neighbourhood trade, transport costs are minimised. Economic rationality goes here hand in hand with respect for the environment, and the ties between neighbours become stronger at the same time. In the environmentally conscious societies of Western Europe, citizens themselves show a tendency to discipline one another and make sure that waste disposal complies with the local law.

In the 1970s, American futurist Alvin Toffler (2006, 2007) noticed that the increasingly fast civilisation changes had led to emergence of a society that consumes and throws away things at a mass scale. The world embedded in the culture of throwing away and transience started to generate huge amounts of waste, sticking to the model of depositing waste in the environment. Being convenient, this model is not easy to abandon. Even the average age of dwelling-houses in the USA (which are commonly regarded as durable goods) has shortened from 100 to 40 years, as people move away from masonry technology. People even built houses meant to be used for a short period of time, as it was then easier to demolish them and erect new ones in their place. 
In his comment to a work by Bertrand (2002), Lester Brown, a known American environmental analyst and pioneer in the field of ecology, presented an interesting example from New York on the issue of waste, where at the threshold of the 21st century, every day around 600 refuse collection lorries, forming convoys $15 \mathrm{~km}$ long, took away 12 thousand tons of waste produced by the city sometimes to places located over $480 \mathrm{~km}$ away. This happened despite the estimate that separation and recycling of paper alone would have reduced the number of New York refuse collection lorries by almost a third, and shortened the traffic-blocking convoys by $4.5 \mathrm{~km}$. Also in the context of the problem of waste, already cited Toffler (2007) gave an interesting example of a clash of cultures. When in the 1950s Americans visited Sweden, they were surprised by how clean the country was. However, after a short period of time (the 1960s) convergence processes made Western Europe more similar to America - then Sweden too became more littered, as consumerism was increasing among the population of the Old Continent.

However, from the post-industrial economy of unsustainability and transience are slowly emerging phenomena that seem to confirm the patterns described by the environmental curve proposed by American economist and Noble Prize Winner Kuznets (Ekologiczna..., 2013). According to this scholar, as the economy develops, pressure on the environment increases, but over time this increase becomes slower, and even the trend becomes reversed. Japan, once one of the most littered countries in the world, within a decade became a leader of rigorous waste separation and innovativeness in searching for new applications for waste. According to Eurostat data, current attitudes of EU residents towards waste also show positive changes. In 2017, the amount of waste per one EU resident was as much as $487 \mathrm{~kg}$, but only $23 \%$ of this waste was deposited at landfill sites. ${ }^{1}$ In 1995, an average EU resident disposed of almost two thirds of their waste in this manner. Today, communities of many Western European countries have almost entirely recovered from the syndrome of "littering one's own nest", which was condemned in the Sciences journal at the end of the 1960s by Hardin (1968) in the context of the tragedy of the commons. We should bear in mind that such commons include the environment in which we try to deposit our waste.

\section{Conclusions}

1) Summing up the discussion about good practice, it is worth citing interesting observations made by American environmentalist and entrepreneur p. Hawken (1996). Hawken looks at the problem of waste through the lens of key conditions of sustainability of socio-economic systems and refers to the laws of nature. According to Hawken, man-made sustainable systems should respect the principle of full recycling. After all, the nature owes its sustainability among other things to the fact that there is nothing such as waste in it. What is unnecessary for one species is key for survival of another species. Thus, the economy of the future is already defined as an economy that, like ecosystems, will rely on multilevel use of waste.

2) The system of functioning of waste management depends on the human factor. Local authorities create organisational and institutional frameworks, which are very important, but it is in fact residents who take actions in the area of waste management: it is up to them how much waste is produced and how it is disposed of.

3) When seeking solutions to local problems of waste management, one should think globally. Many of the interesting good practices are not implemented by the authorities, but developed as part

\footnotetext{
1 Retrieved: http://appsso.eurostat.ec.europa.eu/nui/submitViewTableAction.do Access: 28.01.2019
} 
of bottom-up initiatives. The good news is that in the age of information civilisation these good practices can spread much more easily.

\section{Bibliography}

1. Bertrand, Y., A. (2002). Ziemia z nieba. Portret planety u progu XXI wieku (Earth from heaven. A portrait of the planet at the beginning of the 21st century). Wydawnictwo Swiat Ksiazki, Warszawa, p.15.

2. Carlsberg pokazuje jak zarzadzac opakowaniami w mysl gospodarki obiegu zamknietego (Carlsberg shows how to manage packaging in the closed circuit economy). (2010). Retrieved: https://natemat.pl/196743,carlsberg-pokazuje-jak-zarzadzac-opakowaniami-w-mysl-gospodarki-obieguzamknietego Access: 09.10.2018

3. Co mozna odzyskac ze starych sprzetow (What can be recovered from old hardware). (2010). Retrieved: https://tech.wp.pl/co-mozna-odzyskac-ze-starych-sprzetow-6034887604036737a Access: 09.10.2018

4. Dacko, M. (2011a). Model rozwoju obszarow wiejskich objetych siecia Natura 2000 (Model of development of rural areas covered by the Natura 2000 network). In „Uwarunkowania zrownowazonego rozwoju gmin objetych siecia Natura 2000 w swietle badan empirycznych" ("Conditions for the sustainable development of communes included in the Natura 2000 network in the light of empirical research"). Wydawnictwo Instytutu Rozwoju Wsi i Rolnictwa PAN, Warszawa, pp. 325-360.

5. Dacko, M. (2011b). Koncepcja zrownowazonego rozwoju w naukach ekonomicznych - inspiracje, ewolucja, perspektywy (The concept of sustainable development in economic sciences - inspirations, evolution, perspectives). In „Natura 2000 jako czynnik zrownowazonego rozwoju obszarow wiejskich regionu Zielonych Pluc Polski" (Natura 2000 as a factor in the sustainable development of rural areas of the Green Lungs of Poland"). Wydawnictwo Instytutu Rozwoju Wsi i Rolnictwa PAN, Warszawa, pp. 19-42.

6. Dacko, M., Dacko A. (2018). Studia nad rozwojem obszarow wiejskich - od paradygmatu wzrostu do rezyliencji (Studies on the Development of Rural Areas - from the Growth Paradigm to Resilience). Wies $i$ Rolnictwo 2 (179), pp. 49-64.

7. Dron wytypuje domy w ktorych spalane sa odpady (The drone will select houses in which the waste is incinerated). (2019). Retrieved: https://epainfo.pl/dron-wytypuje-domy-w-ktorych-spalane-sa-odpady-tomozliwe/ Access: 22.01.2019

8. Gospodarka odpadami (Waste management). (2018). Retrieved: http://odpady.stalowawola.pl/gospodarkaodpadami/ Access: 20.09.2018

9. Hardin, G. (1968). The Tragedy of the Commons. Sciences, Volume 162.

10. Hawken, p. (1996). Przez zielone okulary - jak prowadzic interesy nie szkodzac sobie i innym (Through green glasses - how to do business without hurting yourself and others). Wydawnictwo Pust Oblok, Warszawa.

11. Ekologiczna krzywa Kuznetsa (Ecological curve of Kuznets). (2013). Retrieved: http://coin.wne.uw.edu.pl/tzylicz/1303AURA.pdf Access: 20.04.2018

12. Ekonomia cyrkularna - trend ktory moze zatrzymac eksploatowanie planety (Circular economy - a trend that can stop the exploitation of the planet). (2010). Retrieved: https://www.forbes.pl/przywodztwo/ekonomia-cyrkularna-trend-ktory-moze-zatrzymac-eksploatowanieplanety/y6b1lbc Access: 09.10.2018

13. Eurostat. (2017). Retrieved: http://appsso.eurostat.ec.europa.eu/nui/submitViewTableAction.do. Access: 21.01.2019.

14. Kacik rzeczy uzywanych otwarty w Stalowej Woli (The Used Things Corner opened in Stalowa Wola). (2016). Retrieved: https://echodnia.eu/podkarpackie/kacik-rzeczy-uzywanych-otwarty-w-stalowej-woliprzyjmie-niepotrzebne-rzeczy/ar/10003908 Access: 20.09.2018

15. Kuder, D. (2014). Nowe modele wzrostu gospodarczego a paradygmat zrownowazonego rozwoju (New Models of Economic Growth and Paradigm of Sustainable Development). Nierownosci Spoleczne a Wzrost Gospodarczy, Volume 38, pp. 27-39.

16. Matysiak, A., Strus, M. (2015). Paradygmat rozwoju zrownowazonego (Sustainable development paradigm). Studia Ekonomiczne Zeszyty Naukowe Uniwersytetu Ekonomicznego, Volume 213, pp. 11-21.

17. Pierwsza warszawska kawiarenka naprawcza (The first Warsaw restoration cafe). (2018). Retrieved: http://zero-waste.pl/2018/04/10/pierwsza-warszawska-kawiarenka-naprawcza-naszym-okiem/ Access: 23.03.2018

18. Poskrobko, B. (2013). Paradygmat zrownowazonego rozwoju jako wiodacy kanon w badaniu nowych obszarow ekonomii (The Paradigm of Sustainable Development as the Leading Standard in the Research on New Spheres of Economics), Ekonomia i Srodowisko, 3(46), pp. 10-24.

19.Schultink, G. (2007). Sustainable Land Use and Urban Growth Management: Demand-Supply Factors and Strategic Planning Considerations. Journal of Agricultural, Food, and Environmental Sciences, Volume 1, Issue 1, pp. 109-123.

20.Smieci w Japonii (Garbage in Japan). (2017). Retrieved: http://www.gaijinwpodrozy.pl/smieci-w-japonii/ Access: 23.03 .2018

21.Sprawdza co wyrzucasz do smieci (They'll check what you throw into the trash). (2015). Retrieved: https://wpolityce.pl/spoleczenstwo/228199-sprawdza-co-wyrzucasz-do-smieci-worki-na-odpady-z-kodamikreskowymi-i-adresem Access: 20.09.2018 
22. Swiat bez smieci? (A world without rubbish?). (2018). Retrieved:

http://weekend.gazeta.pl/weekend/1,152121,18284522,Swiat_bez_smieci_Poznajcie_filozofie_zerowaste_i .html Access: 23.03.2018

23.Sztumski, W. (2006). Idea zrownowazonego rozwoju a mozliwosci jej urzeczywistnienia (The idea of sustainable development and possibility of its realization). Problemy Ekorozwoju, Volume 1, Issue 2, pp. 7376.

24. System monitorowania odbioru oraz identyfikacji workow z odpadami (Adaptation monitoring system and identification of waste bags). (2018). Retrieved: http://odpady.stalowawola.pl/wpcontent/uploads/2017/12/System-monitorowania-odbioru-oraz-identyfikacji-worków-z-odpadami3.pdf Access: 20.09 .2018

25. Toffler, A. (2006). Trzecia fala (The third wave), Wydawnictwo Kurpisz S.A., Poznan.

26. Toffler, A. (2007). Szok przyszłosci (Future shock), Wydawnictwo Kurpisz S.A., Poznan.

27. Wielki protest w Neapolu (A great protest in Naples). (2013). Retrieved: http://wyborcza.pl/1,76842,14966982,Wielki_protest_w_Neapolu_Toksyczne_odpady_zmienily.html Access: 08.05.2018.

28.Zadroga, A. (2016). Sustainable development jako paradygmat rozwoju spoleczno-gospodarczego (Sustainable development as a paradigm of socio-economic development). In „Przestrzenie badawcze mlodych naukowcow. Inspiracje-Innowacje-Wdrozenia” (,Research spaces of young scientists. InspirationInnovation-Implementation”). Wydawnictwo Katolickiego Uniwersytetu Lubelskiego, Lublin, pp.11-24.

29. Zero waste. (2019). Retrieved: https://zerowastehome.com/about/bea/ Access: 22.01.2019

30. Zobaczyc Neapol i przezyc (See Naples and live). (2010). Retrieved: https://www.newsweek.pl/swiat/zobaczyc-neapol-i-przezyc/5nw599j Access: 26.01.2019.

31.Zobaczyc Neapol i umrzec. Na cholere (See Naples and die. For cholera). (2007). Retrieved: https://www.tygodnikprzeglad.pl/zobaczyc-neapol-umrzec-na-cholere/ Access: 08.05.2018.

32.Zylicz, T. (2010). Czy studentow ekonomii nalezy uczyc o trwalym rozwoju? (Should economics students be taught about sustainable development?). In „Ekonomia zrownowazonego rozwoju. Zarys problemow badawczych i dydaktyki" (The economics of sustainable development. Outline of research problems and didactics), Wydawnictwo Wyzszej Szkoly Ekonomicznej, Bialystok, pp. 84-94. 